(C) 1984. The Genetical Society of Great Britain

\title{
NUCLEOLAR ORGANISER ACTIVITY IN WHEAT-BARLEY CHROMOSOME ADDITION LINES
}

\author{
J. L. SANTOS, J. R. LACADENA, M. C. CERMEÑo AND J. ORELLANA \\ Departamento de Genética, Facultad de Biologia, Universidad Complutense, \\ Madrid-3, Spain
}

Received 26.viii.83

\section{SUMMARY}

\begin{abstract}
The nucleolar organiser activity of cultivated barley, Hordeum vulgare, and the wheat-barley chromosome addition lines is analysed by a modified, highly reproducible, silver-staining procedure. Four $\mathrm{Ag}-\mathrm{NORs}$ are observed in metaphase cells of barley corresponding to chromosomes $5 \mathrm{H}^{\mathrm{v}}$ and $6 \mathrm{H}^{\mathrm{v}}$. Six Ag-NORs are detected in the chromosome addition lines $5 \mathrm{H}^{\mathrm{v}}$ and $6 \mathrm{H}^{\mathrm{v}}$ while only four $\mathrm{Ag}$ NORs are observed in the rest of the addition lines analysed $\left(2 \mathrm{H}^{\mathrm{v}}, 3 \mathrm{H}^{\mathrm{v}}, 4 \mathrm{H}^{\mathrm{v}}\right.$ and $7 \mathrm{H}^{v}$ ). It is concluded that the nucleolar organiser chromosomes $1 \mathrm{~B}, 6 \mathrm{~B}$, $5 \mathrm{H}^{\mathrm{v}}$ and $6 \mathrm{H}^{\mathrm{v}}$ are active. The chromosome $6 \mathrm{H}^{\mathrm{v}}$ of barley seems to control the nucleolar activity of its homoeologous $6 \mathrm{~B}$ of wheat judging from the diminution of the $\mathrm{Ag}-\mathrm{NOR}$ size of chromosome $6 \mathrm{~B}$ in the corresponding addition line.
\end{abstract}

\section{INTRODUCTION}

A modified, highly reproducible, Ag-staining procedure for plant material which enables us to analyse the nucleolar competition has been developed in our laboratory (Lacadena et al., 1984; Cermeño et al., 1983; Orellana et al., 1984). It has been applied to study the activity of nucleolar organiser regions (NORs) since it is known that $\mathrm{Ag}$-staining reaction of NORs (Ag-NORs) at mitotic metaphase can be considered as an indication for genetic activity during the preceding interphase (Miller et al., 1976a, 1976b; Schwarzacher et al., 1978; Schmiady et al., 1979).

In this paper the NOR activity of barley and wheat-barley chromosome addition lines is analysed by using the silver procedure.

\section{MATERIALS AND METHODS}

Plants of common wheat Triticum aestivum, cv. Chinese Spring, barley, Hordeum vulgare, $\mathrm{cv}$. Betzes and the Chinese Spring-Betzes addition lines for chromosomes $2 \mathrm{H}^{\mathrm{v}}, 3 \mathrm{H}^{\mathrm{v}}, 4 \mathrm{H}^{\mathrm{v}}, 5 \mathrm{H}^{\mathrm{v}}, 6 \mathrm{H}^{\mathrm{v}}$ and $7 \mathrm{H}^{\mathrm{v}}$ (kindly supplied by Dr Islam, Waite Agr. Res. Inst., The Univ. of Adelaide) were used (see Islam et al., 1981). Homoeologous nomenclature of barley chromosomes $\left(1 \mathrm{H}^{v}\right.$ to $\left.7 \mathrm{H}^{v}\right)$ has been used.

Seeds were germinated on wetted filter paper in Petri dishes at $20^{\circ} \mathrm{C}$. Primary roots $1 \mathrm{~cm}$ long were excised and immersed in tap water at $0^{\circ} \mathrm{C}$ for $36-48 \mathrm{~h}$ to shorten the chromosomes. Subsequently the tips were fixed in acetic: alcohol $1: 3$.

Somatic metaphase cells were comparatively analysed by phase contrast, $\mathrm{C}$-banding and $\mathrm{Ag}$-staining techniques. The $\mathrm{C}$-banding procedure was carried out according to Giraldez et al., (1979) and the silver-staining method for nucleolar organiser regions as described by Lacadena et al., (1984). 


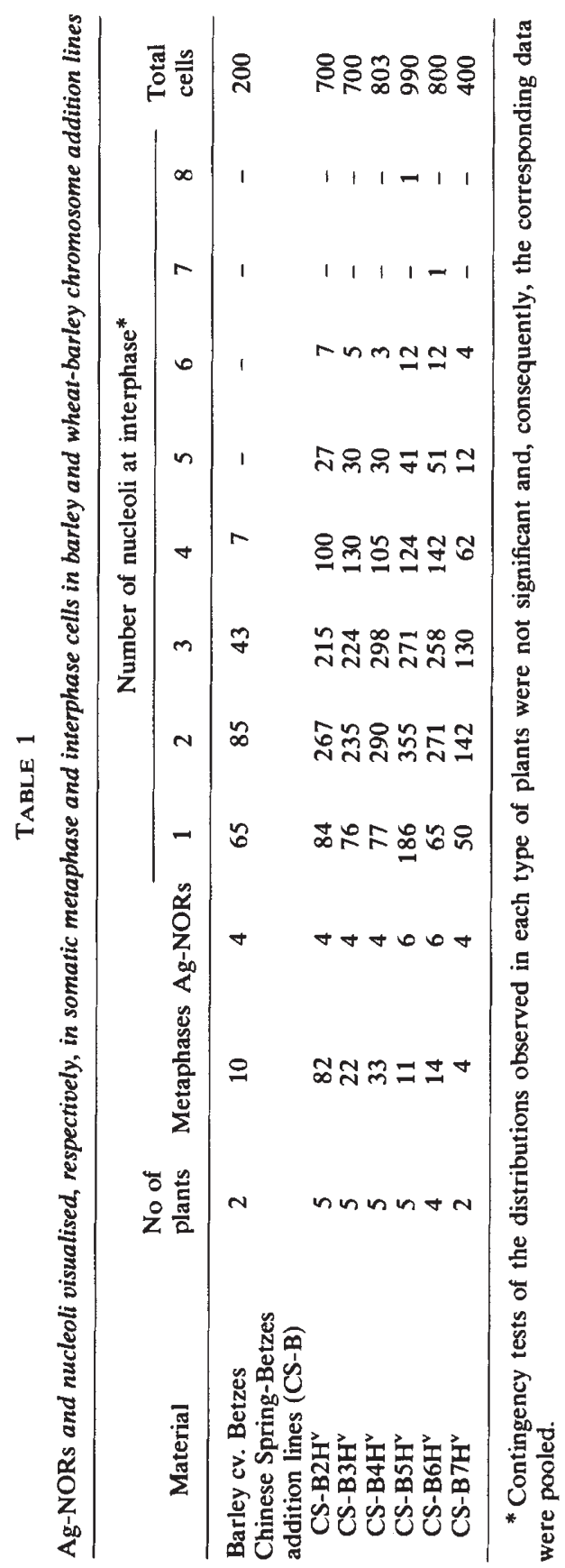




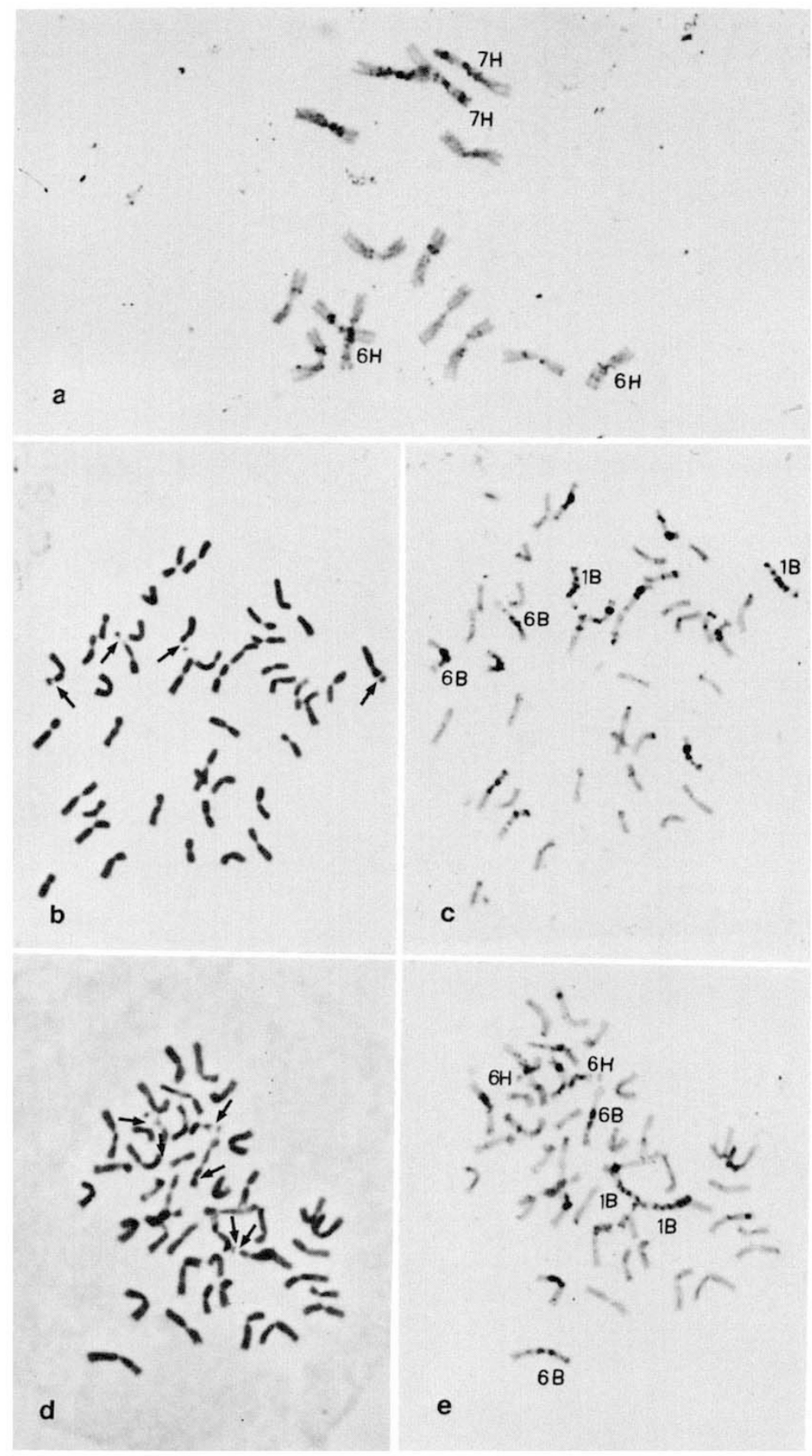

Plate. 1. C-banded metaphase cells of barley cv. Betzes, hexaploid wheat cv. Chinese Spring and wheat-barley $6 \mathrm{H}^{v}$ addition line. (a) C-banded metaphase cell of Betzes trisomic for chromosome $3 \mathrm{H}^{\mathrm{v}}$. (b) and (c) Chinese Spring hexaploid wheat, phase contrast and $\mathrm{C}$-banding of the same cell. ( $\mathrm{d}$ and e) wheat-barley $6 \mathrm{H}^{\mathrm{v}}$ addition line, phase contrast and $\mathrm{C}$-banding of the same cell. Arrows indicate the secondary constrictions. 


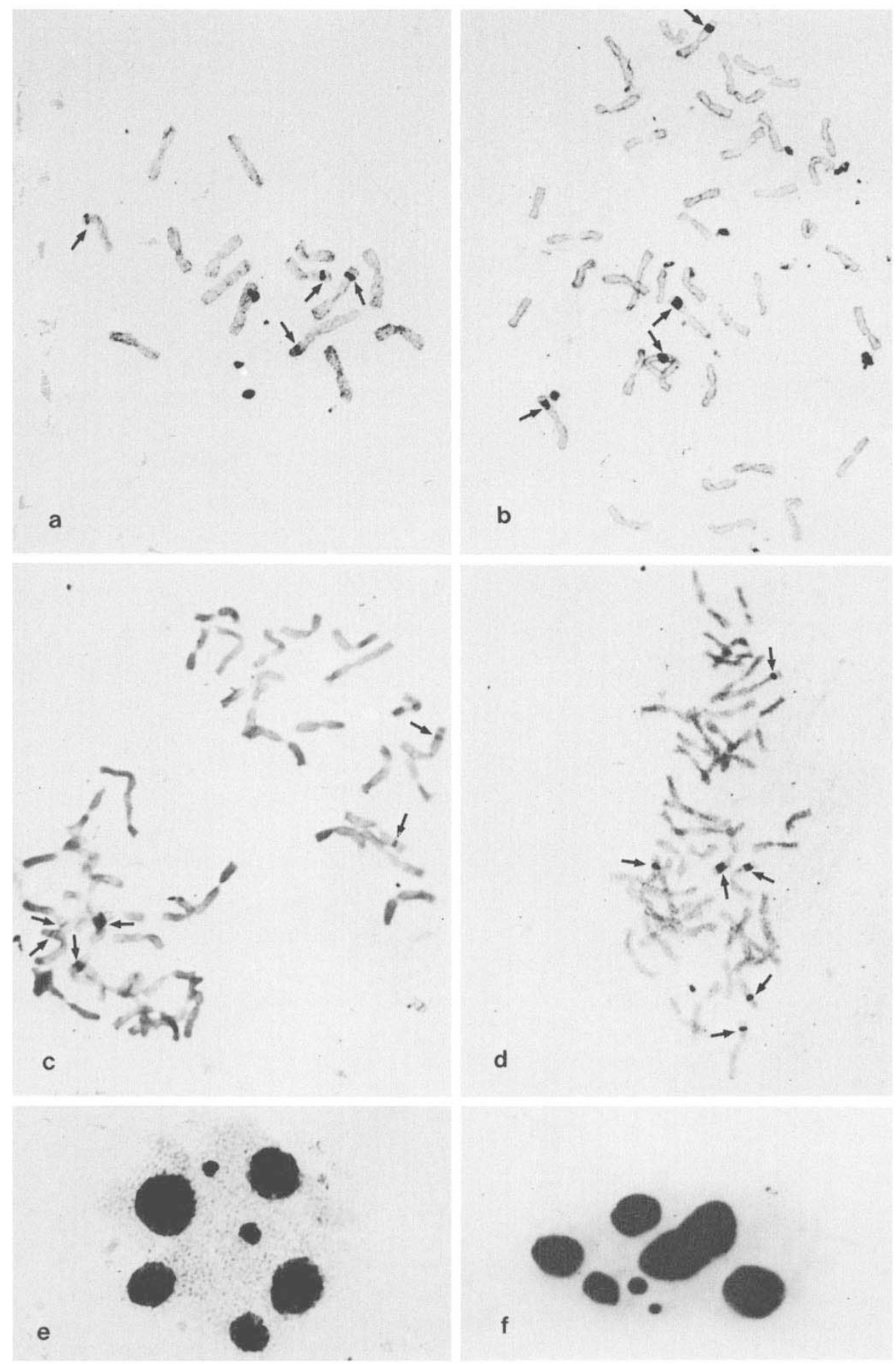

Plate. 2. Ag-stained somatic metaphase cells and interphase cells. (a) diploid barley cv. Betzes trisomic for chromosome $3 \mathrm{H}^{\mathrm{v}}$. (b) hexaploid wheat cv. Chinese Spring. (c) wheat-barley $6 \mathrm{H}^{\mathrm{v}}$ addition line. (d) wheat-barley $5 \mathrm{H}^{\mathrm{v}}$ addition line. (e and $\mathrm{f}$ ) interphase cells with 7 and 8 nuelcoli corresponding to $6 \mathrm{H}^{\mathrm{v}}$ and $5 \mathrm{H}^{\mathrm{v}}$ wheat-barley addition lines, respectively. Arrows indicate Ag-NORs. 


\section{Results}

The nucleolar organiser chromosomes were identified with both phase contrast and C-banding (plate 1). On the other hand, Ag-NORs were also clearly identified (fig. 2) being located in close correspondence with the secondary constriction as observed by phase contrast.

The results obtained are shown in table 1. Four Ag-NORs were observed in all the metaphase cells observed in both the Betzes barley (plate 2(a)) and Chinese Spring wheat (plate 2(b)). In the addition lines for chromosome $5 \mathrm{H}^{v}$ and $6 \mathrm{H}^{\mathrm{v}}$ (the two nucleolar organiser chromosomes of barley), six Ag-NORs were observed in all the metaphase cells analysed (plates 2(c-d)) while in the remainder $\left(2 \mathrm{H}^{\mathrm{v}}, 3 \mathrm{H}^{\mathrm{v}}, 4 \mathrm{H}^{\mathrm{v}}\right.$ and $\left.7 \mathrm{H}^{\mathrm{v}}\right)$ addition lines only four $\mathrm{Ag}-\mathrm{NORS}$ were detected, corresponding to the wheat chromosomes $1 \mathrm{~B}$ and $6 \mathrm{~B}$.

The frequency distributions of the number of necleoli observed at interphase are also shown in table 1.

\section{Discussion}

The C-banding patterns of the nucleolar organiser chromosomes enabled clear identification of the wheat chromosomes 1B and 6B (Lacadena et al., 1984) and the barley chromosomes $5 \mathrm{H}^{v}$ and $6 \mathrm{H}^{v}$ (Islam, 1980; LindeLaursen et al., (1983) in both the parental species and the corresponding addition lines. In consequence, from the results obtained one can conclude that in the Betzes cultivar of barley the NORs of both the $5 \mathrm{H}^{\mathrm{v}}$ and $6 \mathrm{H}^{\mathrm{v}}$ chromosomes are active in interphase since four Ag-NORs are observed in metaphase cells. Both Ag-NORs seem to be of rather a similar size (plate 2(a)). However, Linde-Laursen (1983) has described a nucleolus organiser polymorphism in some barley cultivars. The maximum number of nucleoli observed agrees with the number of $\mathrm{Ag}-\mathrm{NORs}$ present in the cells (table 1). Our results are in agreement with those of Nicoloff et al., (1979).

From the results obtained in the wheat-barley addition lines it can be concluded that the NORs of both the $5 \mathrm{H}^{v}$ and $6 \mathrm{H}^{\mathrm{v}}$ chromosomes of barley are active in addition to those of the wheat chromosomes $1 \mathrm{~B}$ and $6 \mathrm{~B}$ since six Ag-NORs (two from 1B, two from 6B and two others from, respectively, $5 \mathrm{H}^{v}$ or $\left.6 \mathrm{H}^{v}\right)$ are detected in all the metaphase cells observed in the corresponding addition lines (see table 1 ) (plates $2(\mathrm{c}-\mathrm{d})$ ). The maximum number of nucleoli observed at interphase agree quite well with those expected taking into consideration that the Chinese Spring cultivar of wheat shows up to 5 and 6 nucleoli since the NOR of chromosome 5D is active although difficult to detect by silver procedure (Cermeño et al., 1984). This explains the numbers of 7 or 8 nucleoli found in the $5 \mathrm{H}^{v}$ and $6 \mathrm{H}^{v}$ chromosome addition lines (plates $2(\mathrm{e}-\mathrm{f})$ ). It is worth mentioning that two nucleoli appear to be much smaller than the remainder. They are probably formed by the chromosome 5D of wheat.

On the other hand, it has been clearly observed in all (40) metaphase cells of the $6 \mathrm{H}^{\mathrm{v}}$ chromosome addition line that the Ag-NOR size of chromosome $6 \mathrm{~B}$ is greatly reduced in comparison with that of its homoeologous $6 \mathrm{H}^{v}$ (see plates $1(\mathrm{~d}-\mathrm{e})$ and $2(\mathrm{c})$ ). Taking into account that the NOR of chromosome $6 \mathrm{~B}$ possess approximately 60 per cent of the total rRNA gene complement of hexaploid wheat (Flavell and Smith, 1974; Flavell and O'Dell, 1976), one might deduce that its genetic activity has probably been diminished by the 
presence of its homoeologous chromosome $6 \mathrm{H}^{\mathrm{v}}$ of barley. This fact would correspond to a partial differential amphiplasty. It is worth mentioning that Martini et al., (1982) reported a partial inactivation of wheat nucleolus organisers by the nucleolus organiser chromosomes from Aegilops umbellulata.

In previous work we have found that the NOR activity of chromosome $1 \mathrm{R}$ of rye is suppressed by the presence of wheat (Lacadena et al., 1984; Cermeño et al., 1984) and Aegilops ventricosa chromosomes (Orellana et al., 1984). On the other hand, the behaviour of nucleolar organiser activity of Ae. ventricosa chromosomes are similar to those of barley chromosomes since in the amphiploids of several tetraploid wheats and Ae. ventricosa the ventricosa NORs are active (Orellana et al., 1984). These observations are in agreement with those of Ramsay and Dyer (1983) who found that rye NORs are suppressed by the barley chromosomes in the corresponding interspecific hybrid. So, it seems that, for an unknown reason, the rye nucleolar organiser chromosome $1 \mathrm{R}$ is the weakest among the similar chromosomes of cereals and related species.

Acknowledgments. This work has been supported by a grant from the Commision Asesora de Investigación Científica y Técnica of Spain.

\section{REFERENCES}

CERMEÑo, M. C., OREllanA, J., SANTOS, J. L. AND LACADENA, J. R. 1984. Nucleolar organiser activity in wheat, rye and their derivatives detected by a silver-staining procedure. Chromosoma (in press).

FLAVELL, R. B. AND O'DELL, M. 1976. Ribosomal RNA genes on homoeologous chromosomes of groups 5 and 6 in hexaploid wheat. Heredity, 37, 377-385.

FLAVELL, R. B. AND SMITH, D. B. 1974. The role of homoeologous group 1 chromosomes in the control of rRNA genes in wheat. Biochem. Genet., 12, 271-279.

GIRALDEZ, R., CERMEÑo, M. C. AND ORELLANA, J. 1979. Comparison of C-banding pattern in the chromosomes of inbred lines and open pollinated varieties of rye, Secale cereale L. Z. Pflanzenzüchtg., 83, 40-48.

ISLAM, A. K. M. R. 1980. Identification of wheat-barley addition lines with N-banding of chromosomes. Chromosoma, 76, 365-376.

ISLAM, A. K. M. R., SHEPHERD, K. W. AND SPARROW, D. H. B. 1981. Isolation and characterization of euplasmic wheat-barley chromosome addition lines. Heredity, 46, 161-174.

LACADENA, J. R., CERMEÑo, M. C., ORELLANA, J. AND SANTOS, J. L. 1984. Evidence for wheat-rye nucleolar competition (amphiplasty) in Triticale by silver-staining procedure. Theor. Appl. Genet., 67, 207-213.

LINDE-LAURSEN, I. 1983. Nucleolus organizer polymorphism in barley, Hordeum vulgare L. Hereditas, 100 (In press).

LINDE-LAURSEN, I., DOLL, H. AND NIELSEN, G. 1982. Giemsa C-banding patterns and some biochemical markers in a pedigree of European barley. Z. Pflanzenzüchtg., 88, 191-219.

MARTINI, G., O'DELL, M. AND FLAVELL, R. B. 1982. Partial inactivation of wheat nucleolus organisers by the nucleolus organiser chromosomes from Aegilops umbellulata. Chromosoma, 84, 687-700.

MILlER, D. A., DEV, V. G., TANTRAVAHI, R. AND MILlER, O. J. 1976a. Suppression on human nucleolus organizer activity in mouse-human somatic hybrid cells. Exp. Cell Res., $101,235-243$.

MilleR, O. J., MilleR, D. A., DEV, V. G., TANTRAVAHI, R. AND CROCE, C. M. $1976 b$. Expression of human and suppression of mouse nucleolar organizer activity in mousehuman somatic cell hybrids. Proc. Nat. Acad. Sci., 73, 4531-4535.

NICOLOFF, H., ANASTASSOVA-KRISTEVA, M., RIEGER, R. AND KUNZEL, G. 1979. "Nucleolar" as observed in barley translocation lines with specifically reconstructed SAT chromosomes. Theor. Appl. Genet., 55, 247-251. 
OREllana, J., SANTOS, J. L., LACAdena, J. R. AND CeRmeño, M. C. 1984. Nucleolar competition analysis in Aegilops ventricosa and its amphiploids with tetraploid wheats and diploid rye by silver staining procedure. Can. J. Genet. Cytol., (In press).

RAMSAY, G. AND DYER, A. F. 1983. Nucleolar organiser suppression in barley $\times$ rye hybrids. Kew Chromosome Conference II (edited by Brandham, P. E. and Bennett, M. D.), George Allen \& Unwin, p. 361.

SCHMIADY, H., MUNKE, M. AND SPERLING, K. 1979. Ag-staining of nucleolus organizer regions of human prematurely condensed chromosomes from cells with different ribosomal RNA gene activity. Exp. Cell Res., 121, 425-428.

SCHWARZACHER, H. G., MIKELSAAR, A. V. AND SCHNEDL, w. 1978. The nature of the Ag-staining of nucleolus organizer regions: Electron-and light-microscopy studies on human cells in interphase, mitosis and meiosis. Cytogenet. Cell Genet., 20, 24-39. 